medRxiv preprint doi: https://doi.org/10.1101/2021.05.28.21257947; this version posted May 31, 2021. The copyright holder for this preprint

(which was not certified by peer review) is the author/funder, who has granted medRxiv a license to display the preprint in perpetuity.

It is made available under a CC-BY-NC 4.0 International license .

\title{
Pharmacological Management of Acute Spinal Cord Injury: A longitudinal multi-cohort observational study
}

Catherine R. Jutzeler, $\mathrm{PhD}^{*}$; Lucie Bourguignon, MSc; Bobo Tong, MPH; Elias Ronca, PhD; Eric Bailey, BS; Noam Y. Harel, MD PhD; Fred Geisler; MD PhD; Adam R. Ferguson, PhD; Brian K. Kwon, MD PhD; Jacquelyn J.

$\mathrm{Cragg}^{\delta}, \mathrm{PhD} ;$ Lukas Grassner, $\mathrm{MD} \mathrm{PhD}^{\delta}$; and John L.K. Kramer, $\mathrm{PhD}^{\delta}$

\author{
"Corresponding Author: \\ Catherine R. Jutzeler \\ Mattenstrasse 26 \\ 4058 Basel \\ Switzerland \\ Catherine.Jutzeler@bsse.ethz.ch \\ ${ }^{\delta}$ Shared Senior Authorship
}

\begin{abstract}
Affiliation Information for All Authors:
Catherine Jutzeler: Department of Biosystems Science and Engineering, ETH Zurich and SIB Swiss Institute of Bioinformatics, Basel, Switzerland.

Bobo Tong: International Collaboration on Repair Discoveries (ICORD), University of British Columbia, Vancouver, Canada.

Lucie Bourguignon: Department of Biosystems Science and Engineering, ETH Zurich and SIB Swiss Institute of Bioinformatics, Basel, Switzerland.

Elias Ronca: Swiss Paraplegic Research, Nottwil, Switzerland

Eric Bailey: James J Peters Veterans Affairs Medical Center, Bronx, New York, USA.

Noam Y. Harel: James J Peters Veterans Affairs Medical Center, Bronx, New York; Icahn School of Medicine at Mount Sinai, New York, New York, USA.

Fred Geisler: University of Saskatchewan, Saskatoon, Saskatchewan, Canada

Adam R. Ferguson: Brain and Spinal Injury Center, Weill Institute for Neurosciences, University of California San Francisco (UCSF), San Francisco, CA; San Francisco Veteran's Affairs Health Care System, San Francisco, CA, USA.

Brian K. Kwon: International Collaboration on Repair Discoveries (ICORD), University of British Columbia, Vancouver, Canada.

Jacquelyn J. Cragg: Faculty of Pharmaceutical Sciences, University of British Columbia, Vancouver, Canada. International Collaboration on Repair Discoveries (ICORD), University of British Columbia, Vancouver, Canada.

Lukas Grassner: Department of Neurosurgery, Medical University Innsbruck, Innsbruck, Austria; Institute of Molecular Regenerative Medicine, Spinal Cord Injury and Tissue Regeneration Center Salzburg, Paracelsus Medical University, Salzburg, Austria.

John Kramer: International Collaboration on Repair Discoveries (ICORD), University of British Columbia, Vancouver, Canada; Djavad Mowafaghian Centre for Brain Health, University of British Columbia, Vancouver, Canada; Department of Anesthesiology, Pharmacology, and Therapeutics, Faculty of Medicine, University of British Columbia, Canada; Hugill Centre for Anesthesia, University of British Columbia, Vancouver, Canada.
\end{abstract}

\section{Contributions}

Catherine R. Jutzeler: Study concept/design, data entry, data cleaning, data analyses, interpretation of data, and drafting the manuscript

Bobo Tong: Data cleaning, interpretation of data and revising the manuscript for intellectual content

NOTE: This preprint reports new research that has not been certified'by peer review and should not be used to guide clinical practice. 
Lucie Bourguignon: Interpretation of data and revising the manuscript for intellectual content

Elias Ronca: Interpretation of data and revising the manuscript for intellectual content

Eric Bailey: Primary data collection, interpretation of data, and revising the manuscript for intellectual content

Noam Y. Harel: Data cleaning, interpretation of data, and revising the manuscript for intellectual content

Fred Geisler: Data cleaning, interpretation of data, and revising the manuscript for intellectual content

Adam R. Ferguson: Interpretation of data, revising the manuscript for intellectual content

Brian K. Kwon: Interpretation of data, revising the manuscript for intellectual content

Jacquelyn J. Cragg: Interpretation of data, revising the manuscript for intellectual content

Lukas Grassner: Study concept/design, interpretation of data, revising the manuscript for intellectual content

John LK Kramer: study concept/design, interpretation of data, and revising the manuscript for intellectual content

Number of characters in title: 104

Abstract word count: 245

Word count of main text: 3104

Number of Tables: 1

Number of Figures: 4

Number of References: 69

Supplemental material: 7 Tables and 0 Figures

Statistical Analyses completed by: Dr. Catherine Jutzeler (Swiss Federal Institute of Technology, ETH Zurich)

Search Terms: [266] Spinal cord trauma; [54] Cohort studies

Acknowledgments: The authors would like to acknowledge the participating centers in the Sygen trial and SCIRehab network that were involved in the patient care and collection of data necessary for this study.

Study Funding: This study was funded by research grants from the Swiss National Science Foundation (Ambizione Grant \#PZ00P3_186101, Jutzeler), Wings for Life Research Foundation (\#2017_044, Jutzeler and Kramer), and Craig H. Nielsen Foundation (Cragg and Jutzeler).

Disclosures: CR. Jutzeler reports no disclosures relevant to the manuscript. B. Tong reports no disclosures. L. Bourguignon reports no disclosures relevant to the manuscript. E. Ronca reports no disclosures relevant to the manuscript. E. Bailey reports no disclosures relevant to the manuscript. NY. Harel reports no disclosures relevant to the manuscript. F. Geisler reports no disclosures relevant to the manuscript. AR. Ferguson reports no disclosures relevant to the manuscript. BK. Kwon reports no disclosures relevant to the manuscript. JJ. Cragg reports no disclosures relevant to the manuscript. L. Grassner reports no disclosures relevant to the manuscript. JLK. Kramer reports no disclosures relevant to the manuscript.

Email addresses of co-authors:

Bobo Tong: 310bobotong@ gmail.com

Lucie Bourguignon: Lucie.Bourguignon@bsse.ethz.ch

Elias Ronca: elias.ronca@ paraplegie.ch

Eric Bailey: Ebailey4@ student.touro.edu

Noam Y. Harel: noam.harel@ mountsinai.org

Fred Geisler: fgeisler@ gmail.com

Adam Ferguson: Adam.Ferguson@ucsf.edu

Brian Kwon: brian.kwon@ubc.ca

Jacquelyn J. Cragg: jacquelyn.cragg@icord.org 
medRxiv preprint doi: https://doi.org/10.1101/2021.05.28.21257947; this version posted May 31, 2021. The copyright holder for this preprint (which was not certified by peer review) is the author/funder, who has granted medRxiv a license to display the preprint in perpetuity.

\section{It is made available under a CC-BY-NC 4.0 International license .}

Lukas Grassner: lukas.grassner@gmail.com

John L.K. Kramer: kramer@icord.org 
medRxiv preprint doi: https://doi.org/10.1101/2021.05.28.21257947; this version posted May 31, 2021. The copyright holder for this preprint (which was not certified by peer review) is the author/funder, who has granted medRxiv a license to display the preprint in perpetuity.

It is made available under a CC-BY-NC 4.0 International license.

\begin{abstract}
Background: Nearly every individual sustaining traumatic spinal cord injury receives multiple types and classes of medications to manage a litany of secondary complications. Prior clinical studies and evidence from animal models suggest that several of these medications could enhance or impede endogenous neurological recovery. However, there is a knowledge gap surrounding the spectrum of pharmacologic agents typically administered in the routine management of spinal cord injury.
\end{abstract}

Objective: To systematically determine the types of medications commonly administered, alone or in combination, in the acute to subacute phase of spinal cord injury.

Methods: We conducted an analysis of two largescale cohorts (the Sygen interventional trial and the SCIRehab observational cohort study) to determine what constitutes "standards of acute pharmacological care" after spinal cord injury. Concomitant medication use, including dosage, timing and reason for administration, was tracked. Descriptive statistics were used to describe the medications administered within the first 60 days after spinal cord injury.

Results: Across 2040 individuals with spinal cord injury, 775 unique medications were administered within the two months after injury. On average, patients enrolled in the Sygen trial received $9.9 \pm 4.9$ (range 0-34), 14.3 \pm 6.3 (range 1-40), 18.6 \pm 8.2 (range 0-58), and $21.5 \pm 9.7$ (range 0-59) medications within the first 7, 14, 30, and 60 days post-injury, respectively. Patients enrolled in the SCIRehab cohort study received on average 1.7 \pm 1.7 (range 0-11), $3.7 \pm 3.7$ (range 0-24), $8.5 \pm 6.3$ (range 0-42), and $13.5 \pm 8.3$ (range 0-52) medications within the first 7, 14, 30, and 60 days post-injury, respectively. Polypharmacy was commonplace (up to 43 medications per day per patient). Approximately $10 \%$ of medications were administered acutely as prophylaxis (e.g., against the development of pain or infections).

Conclusions: To our knowledge, this was the first time acute pharmacological practices have been comprehensively examined after spinal cord injury. Our study revealed a high degree of polypharmacy in the acute stages of spinal cord injury, with potential to both positively and negatively impact neurological recovery. This data may provide key insight to achieve better understanding of how the acute pharmacological management of spinal cord injury affects long-term recovery. All results can be interactively explored on the $R_{X} S C I$ web site (https://jutzelec.shinyapps.io/RxSCI/) and GitHub repository (https://github.com/jutzca/Acute-PharmacologicalTreatment-in-SCI/). 


\section{INTRODUCTION}

Traumatic spinal cord injury is a neurological condition associated with varying degrees of paralysis, sensory impairments, and autonomic deficits. ${ }^{1}$ At present, there are no pharmacological interventions available to enhance the extent a person neurologically or functionally recovers from acute spinal cord injury. ${ }^{2,3}$ In the absence of such an intervention, acute care chiefly focuses on managing the neurological sequela of spinal cord injury as well as emerging secondary complications, including infections, pain, and cardiovascular problems. ${ }^{4}$

Recent observational studies have reported a potential beneficial effect of acutely administered gabapentionoid medications (but not other anticonvulsants) on long-term neurological outcomes after spinal cord injury. ${ }^{5-7}$ Subsequent preclinical studies demonstrated a potential gabapentionoids-meditated mechanism for enhanced recovery, as well as confirmed behavioral benefits in animal models. ${ }^{8.9}$ While efficacy awaits confirmation in prospective clinical trials, these collective observations point to the promise of a reverse translational approach (bedside-to-bench) to restore neurological function after spinal cord injury. Identifying other opportunities for drug repurposing depends, in part, on knowledge regarding specific medications commonly administered in the acute phase. Additionally, if promising pharmacologic agents are to be proposed for human evaluation in clinical trials of acute spinal cord injury, it is important to consider the spectrum of other concomitant medications that are routinely administered in the care of these patients, as they may have known interactions with the promising agent in question. The aim of this study was to comprehensively characterize the pharmacological management of acute spinal cord injury. To this end, we leveraged available clinical trial and observational study data to determine the type, timing, and reason for administration associated with common medications. 
medRxiv preprint doi: https://doi.org/10.1101/2021.05.28.21257947; this version posted May 31, 2021. The copyright holder for this preprint (which was not certified by peer review) is the author/funder, who has granted medRxiv a license to display the preprint in perpetuity. It is made available under a CC-BY-NC 4.0 International license .

\section{METHODS}

\section{Study design}

The design and reporting of this analysis adhered to the STROBE guidelines for observational studies. ${ }^{10}$

\section{Data source and cohort definition}

To quantify medications commonly administered in the acute management of spinal cord injury, we analyzed two sources of data. Both sources represent collections of data from the United States, the first (i.e., trial) between 1992 and 1998 and the second (i.e., observational) from 2007-2009.

The first source comprised details of concomitant medications administered in a clinical trial - the Sygen trial delivering GM-1 ganglioside in acute spinal cord injury. ${ }^{2,11}$ The Sygen trial was a randomized, prospective, phase III, placebo controlled, multi-center study testing the efficacy of GM-1 ganglioside therapy in acute, traumatic spinal cord injury. ${ }^{2,11}$ Full design, recruitment, and enrollment details have been published previously. ${ }^{13}$ Briefly, to be included in the Sygen trial patients were required to have at least one lower extremity with a substantial motor deficit. Patients with spinal cord transection or penetration were excluded, as were patients with a cauda equina, brachial or lumbosacral plexus, or peripheral nerve injury. Multiple trauma cases were included as long as they were not so severe as to preclude neurologic evaluation. Patients with major head trauma, major chest trauma, or intubation were also excluded. With 797 enrolled patients followed over the first year following injury, the Sygen trial was the largest clinical trial ever conducted in the field of spinal cord injury. The Sygen trial, which followed patients over the first year following injury, was clinically active from 1992 to 1998, and showed no differences between treatment and placebo groups in terms of neurological recovery. ${ }^{2}$ The negative finding of the Sygen study is considered Class I Medical Evidence by the spinal cord injury Committee of the American Association of Neurological Surgeons (AANS) and the Congress of Neurological Surgeons (CNS). ${ }^{12,13}$ Subsequent analyses of the Sygen data have been performed to characterize the trajectory and extent of spontaneous recovery from acute spinal cord injury. ${ }^{14,15}$

Our second source of data was from a large, observational study (i.e., SCIRehab), which abstracted information pertaining to medication use in the acute phase of spinal cord injury from patient medical records. ${ }^{16}$ The SCIRehab study enrolled, upon consent, individuals aged $\geq 12$ years with traumatic spinal cord injury who were rehabilitated at six participating rehabilitation centers from 2007 through 2009. ${ }^{17}$ Participating centers included Rocky Mountain Regional Spinal Injury System at Craig Hospital, Shepherd Center, Atlanta GA; Rehabilitation Institute of Chicago, Chicago, IL; Carolinas Rehabilitation, Charlotte, NC; the Mount Sinai Medical Center, New York, NY; and National Rehabilitation Hospital, Washington, DC. Patients were followed for the first-year post-injury and were excluded if they spent two or more weeks at a non-participating rehabilitation center. Details of more than 460,000 interventions provided to 1500 patients were documented by over 1000 clinicians at the six participating centers. Patient demographics and injury characteristics were extracted from the patient medical record (part of the National Institute on Disability and Rehabilitation Research Spinal Cord Injury Model Systems Form I). Design, recruitment, inclusion criteria, and enrollment details have been previously described in detail. ${ }^{17}$

To be included in our study, information on medications administered needed to be available for the patients.

\section{Commonly administered medications}


medRxiv preprint doi: https://doi.org/10.1101/2021.05.28.21257947; this version posted May 31, 2021. The copyright holder for this preprint (which was not certified by peer review) is the author/funder, who has granted medRxiv a license to display the preprint in perpetuity. It is made available under a CC-BY-NC 4.0 International license .

In the Sygen trial, alongside serious adverse events, concomitant medication information was routinely tracked following standardized case report forms by trained examiners in clinical trials as a measure of safety. For each concomitant medication administered during the trial, the reason for administration, dosage, dosing (i.e., start and end date, frequency), and reason for conclusion were recorded. It was also documented in case medications were administered for prophylactic reasons (e.g., to prevent deep vein thrombosis). Note that, although patients were randomized to GM-1 ganglioside therapy, individuals were not randomized to any concomitant medication administered and were managed according to the conventional care protocols of the enrolling center. The SCIRehab study documented the use of all commonly administered medications. For each medication administered, route, dosage and dosing (i.e., start and end date, frequency) were abstracted directly from medical records. However, medication indication was not recorded.

\section{Medication data cleaning and organizing}

Medication data from the Sygen trial and SCIRehab study were separately cleaned and organized. From the medication files, which exist for each patient in the Sygen trial and SCIRehab, we extracted generic medication name and information on dosing (i.e., start and end date, frequency). As information on medication indication (i.e., reasons for administering a medication) was not entered in a standardized fashion during data collection, we classified the medication indication according to the Common Terminology Criteria for Adverse Events (CTCAE). ${ }^{18}$ Briefly, each indication was assigned to a System Organ Class (SOC) ${ }^{18}$ the highest level of the MedDRA hierarchy. ${ }^{19}$ The SOC is identified by anatomical or physiological system, etiology, or purpose (e.g., SOC Investigations for laboratory test results) and comprises 26 different categories. We added a separate class for trauma-related pain (i.e., nociceptive and neuropathic). The rationale for this amendment stems from the fact that the CTCAE does not sufficiently cover this category.

\section{Assessment of blood brain barrier (BBB) permeability}

Leveraging the information from the DrugBank database (www.drugbank.ca), we determined which medications have the ability to cross the blood brain barrier. In case corresponding information was missing in the DrugBank, we searched PubMed for evidence.

\section{Statistical analysis and data visualization}

R Statistical Software version 3.6.3 (Running under: macOS Mojave 10.14.4) was used for all analyses and to visualize the results. Descriptive statistics (mean, standard deviation, ranges, and proportions) were used to describe the patients' demographics, injury characteristics, and medication information. For the latter, this included the number and type of medications administered, reason for administration, and how many medications each patient received per day (i.e., point prevalence). Type and frequency of medications that were administered prophylactically were also computed.

\section{Interactive Web Platform $R_{X} S C I$}

In order to enable the spinal cord injury community, researchers, authorities, and policymakers to fully explore the data and results of this study (and beyond), we developed the freely available and open source $R_{X} S C I$ web platform. $R_{X} S C I$ was implemented with the Shiny framework, ${ }^{20}$ which combines the computational power of the free statistical 
software $\mathrm{R}^{21}$ with friendly and interactive web interfaces. Both, the front- and back-end of $R_{X} S C I$ have been built using the shiny dashboard package. ${ }^{22} R_{X} S C I$ is available as an online application and is hosted at https://jutzelec.shinyapps.io/RxSCI/ and can be accessed via any web browser on any device (e.g., desktop computers, laptops, tablets, smartphones). $R_{X} S C I$ is published under the BSD 3-Clause License. The source code of Neurosurveillance is available through Github at https://github.com/jutzca/Acute-Pharmacological-Treatment-in$\underline{\mathrm{SCI} / \text { tree/master/shinyapp. }}$

\section{Data sharing and code availability}

Full anonymized data of both data sources will be shared at the request from any qualified investigator (please contact the Corresponding Author). The code for the data analysis and visualization is available in our GitHub repository (https://github.com/jutzca/Acute-Pharmacological-Treatment-in-SCI/).

\section{Standard Protocol Approvals, Registrations, and Patient Consents}

Approval for this study (secondary analysis) was received by an institutional ethical standards committee on human experimentation at the University of British Columbia. The original Sygen clinical trial (results published elsewhere) also received ethical approval, but was conducted before clinical trials were required to be registered (i.e., no clinicaltrial.gov identifier available) $)^{2,23}$. Each participating center of the SCIRehab study received institutional review board approval for this study and obtained informed consent from each patient (or their parent/guardian). 
medRxiv preprint doi: https://doi.org/10.1101/2021.05.28.21257947; this version posted May 31, 2021. The copyright holder for this preprint (which was not certified by peer review) is the author/funder, who has granted medRxiv a license to display the preprint in perpetuity. It is made available under a CC-BY-NC 4.0 International license .

\section{RESULTS}

\section{Patient Characteristics and Summary Statistics}

We included 797 and 1243 patients from the Sygen clinical trial and SCIRehab observational study, respectively. While all patients from the Sygen study were included in our analysis, we had to exclude 275 patients from the SCIRehab study due to missing data on medications $(n=241)$ or absence spinal cord injury (i.e., AIS E, cauda equine or peripheral nervous system injuries, $n=14$ ). In both cohorts, the ratio between male and female patients was approximately 4:1, the majority of the patients were injured at the cervical levels (Sygen: 75.2\%; SCIRehab: 60.4\%) and sustained a motor complete injury (Sygen: 65.7\%; SCIRehab: 65.6\%). The most frequent cause of injury was car accidents (Sygen: 47.9\%; SCIRehab: 35.5\%) followed by falls (Sygen: 16.2\%; SCIRehab: 24.1\%). Detailed description of both cohorts is provided in Table 1.

\section{Acute pharmacological management after spinal cord injury}

In total, 489 (trial) and 575 (observational study) unique medications were administered over the course of 60 days after spinal cord injury. More than a third ( $\mathrm{n}=289$ [ 37.3\%]) of the medications administered were common to both data sources (for details see Table e1). Medications were administered to manage secondary complications arising from 20 different system organ classes or to facilitate surgical and medical procedures (Figure 1A). On average, patients enrolled in the Sygen trial received $9.9 \pm 4.9$ (range 0-34), $14.3 \pm 6.3$ (range 1-40), $18.6 \pm 8.2$ (range 0-58), and $21.5 \pm 9.7$ (range 0-59) medications within the first 7, 14, 30, and 60 days post-injury, respectively (Figure 1B). Patients enrolled in the SCIRehab cohort study received on average $1.7 \pm 1.7$ (range 0-11), $3.7 \pm 3.7$ (range 0-24), $8.5 \pm 6.3$ (range 0-42), and $13.5 \pm 8.3$ (range 0-52) medications within the first $7,14,30$, and 60 days post-injury, respectively (Figure 1C). The disparity between Sygen and SCIRehab in the first month post injury can be attributed to different time-points of patient enrollment, with the Sygen trial enrolling patients within 72 hours, compared to SCIRehab, which enrolled patients within days or weeks of injury (Table 1). As a result, medications for first-line trauma management (e.g., nitroglycerin, dopamine) as well as surgical and medical procedures (e.g., isoflurane, vecuronium bromide) are only captured by the Sygen trial. Acetaminophen (analgesic, $n=674$ patients), morphine (analgesic, $\mathrm{n}=664$ patients), and heparin (anticoagulant, $\mathrm{n}=505$ patients) were the three most commonly administered medications in the Sygen trial (Figure 1D). Similarly, in the SCIRehab study, the analgesic acetaminophen ( $\mathrm{n}=924$ patients) was the most commonly administered medication, followed by the laxative docusate ( $\mathrm{n}=862$ patients) and the analgesic combination medicine acetaminophen $\&$ oxycodone $(\mathrm{n}=603$ patients)

(Figure 1E).

The majority of patients enrolled in the Sygen trial required medications to treat secondary complications arising from the gastrointestinal system $(\mathrm{n}=752,95.1 \%)$, pain $(\mathrm{n}=742,93.8 \%)$, infections $(\mathrm{n}=737,93.2 \%)$, and psychiatric issues ( $\mathrm{n}=650,82.2 \%$ ) (Figure 2A, Table e2). A total of 150, 99, and 93 unique medications were administered to treat a variety of secondary complications arising from infections, respiratory system, and gastrointestinal system, respectively. Moreover, pain (e.g., musculoskeletal), gastrointestinal complications (e.g., heartburn, ulcers), and infections (i.e., bacteria, viral, and fungal) were the most frequently managed problems (Figure 2B, Table e3). This was also true when stratifying for injury severity (AIS grades, Table e4). While 
medRxiv preprint doi: https://doi.org/10.1101/2021.05.28.21257947; this version posted May 31, 2021. The copyright holder for this preprint (which was not certified by peer review) is the author/funder, who has granted medRxiv a license to display the preprint in perpetuity. It is made available under a CC-BY-NC 4.0 International license .

infections were mainly treated with antibiotics, antifungal, and antiviral medications depending on their nature, complications arising from gastrointestinal tract were targeted with analgesics, antibiotics, antacids, antiulcer, antianemics, anticholinergics, anticonvulsants, and antispasmodics (see detailed overview in Table e5).

\section{Polypharmacy}

As illustrated in Figures 3, polypharmacy was commonplace. Almost every patient enrolled the Sygen trial or the SCIRehab study received multiple medications per day (Figure 3A). Patients with more severe injuries (AIS A and B) received slightly more medications per day than those with less severe injuries (AIS D). The number of medications administered per day per patient ranged between 1 and 30 for patients enrolled in Sygen trial (Figure 3B) and between 1 and 43 for patients enrolled in the SCIRehab study (Figure 3B). Individual patient examples of the extend of polypharmacy is shown in Figure 3C. The complexity of the combination of medications administered is illustrated in Figure 3D. In the Sygen trial, the three most common combinations of medications were acetaminophen and morphine ( $\mathrm{n}=164$ patients), morphine and ranitidine ( $\mathrm{n}=128$ patients), as well as acetaminophen and heparin ( $\mathrm{n}=123$ patients). In the SCIRehab study, acetaminophen and acetaminophen oxycodone was the most common combination of medications ( $n=480$ patients), followed by acetaminophen and acetaminophen hydrocodone ( $\mathrm{n}=407$ patients) as well as acetaminophen and ibuprofen ( $\mathrm{n}=346$ patients.) The complexity of the combination of medications administered to patients in the SCIRehab study is illustrated in Figure 3E.

\section{Blood brain barrier (BBB) permeability}

Out of the 775 unique medications, 59.4\% $(n=460)$ have the ability to cross the BBB while $20.6 \%(n=160)$ are not permeable for the BBB. No information regarding the BBB permeability could be found for the remaining $20.0 \%$ (n = 155). Detailed information on the permeability can be found in Table e6. Drugs that cross the BBB may be more likely to have effects (positive or negative) on neural recovery pathways after injury.

\section{Prophylactic administration of medications}

Approximately 10\% ( $\mathrm{n}=2,838)$ of all recorded indications in the Sygen trial (Figure 4A) were labelled 'prophylactic' or 'preventative'. A total of 137 unique medications were administered for prophylactic treatment to prevent a wide range of secondary complications (Figure 4B). The major medication groups included antihistamines (ranitidine, famotidine), anticoagulants (heparin, warfarin), and antibiotics (cefazolin, gentamicin) for the prevention of secondary complications arising from the gastrointestinal system (e.g., heart burn, gastric ulcers), blood and vasculature system (e.g., deep vein thrombosis), and infections, respectively (Figure 4C). The majority of patient enrolled in the Sygen trial $\left(n=666\right.$ [83.6\%]) received prophylactic treatments ( mean $_{\text {medications/patient }}=3$ [range 1-21]; mean $_{\text {indications/patient }}=4.3$ [range 1-33]) (Figure 4D). Table e7 provides a comprehensive overview of all medications (and their respective indications) that were used for prophylactic treatment.

\section{Interactive Web Platform $R_{X} S C I$}

The Neurosurveillance web platform is hosted online (https://jutzelec.shinyapps.io/RxSCI/) and contains three main data visualization parts: (1) epidemiological features, including demographics and injury characteristic; (2) information on the pharmacological treatment of spinal cord injury patients on daily basis, including medication 
medRxiv preprint doi: https://doi.org/10.1101/2021.05.28.21257947; this version posted May 31, 2021. The copyright holder for this preprint (which was not certified by peer review) is the author/funder, who has granted medRxiv a license to display the preprint in perpetuity.

It is made available under a CC-BY-NC 4.0 International license .

administration patterns; and (3) visualization of the polypharmacy. All data from the Sygen clinical trial and the SCIRehab study, which was used in this study, can be explored in a customized fashion (e.g., customized selection of patient groups). The platform is configured such that existing or newly generated data sets can be added if they comply with GDPR 
medRxiv preprint doi: https://doi.org/10.1101/2021.05.28.21257947; this version posted May 31, 2021. The copyright holder for this preprint

(which was not certified by peer review) is the author/funder, who has granted medRxiv a license to display the preprint in perpetuity.

It is made available under a CC-BY-NC 4.0 International license .

\section{DISCUSSION}

The aim of the current study was to comprehensively evaluate pharmacological management practices in acute spinal cord injury. To this end, two large data sources were examined, one from a clinical trial and the other from an observational study. Our analysis revealed an incredibly high rate of polypharmacy spread over the course of the first 60 days' post injury, which was administered to manage various health conditions arising directly or indirectly from acute spinal cord injury. Various medications were administered, including those that readily cross the BBB as well as the spinal cord blood barrier (e.g., pregabalin, ${ }^{24}$ morphine ${ }^{25}$ ) to manage the sequela of spinal cord injury (e.g., neuropathic pain), as well as other complex medical complications.

To our knowledge, this was the first time acute pharmacological practices have been comprehensively examined after spinal cord injury. Even considering its extreme and traumatic nature, the sheer number of medications administered in a short window of time after spinal cord injury, over the course of the two months, was remarkably high. This led to a very high degree of polypharmacy. For comparison, polypharmacy in other complex health conditions is generally considered more than five medications $\mathrm{s}^{26,27}$ - the average for acute spinal cord injury patients was approximately double that threshold. While perhaps startling, there is no doubt that aggressive pharmacologic management is typically required due to the complexity of managing spinal cord injury requires aggressive pharmacological management. Nevertheless, the lack of attention paid to the question of "neurological safety" (i.e., whether use of a medication or its interaction with other medications in the acute phase of injury will have long-term and detrimental neurological consequences) is surprising, as is the fact that few attempts have been made to discern potential beneficial (or detrimental) effects of medications that readily cross the BBB. Furthermore, one must consider potential interactions between the high number of clinically used concomitant medications with novel medications and biologics being trialed for improving recovery from spinal cord injury.

The limited knowledge about the potential effects of acutely administered medications on recovery in humans becomes all the more curious considering that a number of these medications alter outcomes in animal studies. As an example, pregabalin, a potent calcium channel blocker and anticonvulsant administered for neuropathic pain, has been repeatedly shown to benefit recovery after spinal cord injury in animal and human spinal cord injury. $5,6,8,9$ Detrimental effects were also observed for some medications, including opioids, which attenuated the recovery of locomotor function and exacerbated pathophysiological processes in rodent models of spinal cord injury. ${ }^{28,29} \mathrm{~A}$ detrimental opioid effect is in line with beneficial effects of naloxone (i.e., opioid antagonist), ${ }^{30-32}$ and is highly concerning in light of the fact that opioids are ubiquitously administered for pain management in the early stages of injury (to $>80 \%$ of the patients). While completely removing or restricting opioids would be highly problematic and present with serious ethical concerns (i.e., weighing the management of acute pain with long-term neurological effects), opioids were among medications commonly administered to prevent the onset of pain. This suggests that opioids, at least in a proportion of patients, were prescribed with the intention to prevent the onset of pain, despite a lack of evidence. ${ }^{33}$ Among these individuals, neurological recovery could perhaps be facilitated by minimizing the administration of opioids. Many other common medications (up to 10\%) are prophylactically administered, including acetaminophen, cefazolin, and famotidine for pain/fever, infection, and ulcer prophylaxis, respectively. 
Despite years of use in clinical routine, safety information with respect to neurological outcomes of many concomitant medications is currently not available. This is highly concerning because fundamental assumptions of pharmacokinetics and -dynamics may not apply as in other (healthy) individuals. ${ }^{34}$ Alterations in physiology lead to prolonged absorption as a consequence of slowed gastric emptying and gastrointestinal motility, ${ }^{35,36}$ altered distribution due to leaky blood spinal cord barrier, ${ }^{37-39}$ hampered metabolism, ${ }^{37,40,41}$ and slowed excretion are hallmarks of this altered physiology. ${ }^{39,41,42}$ Examples of medications with changed pharmacokinetics are amikacin, baclofen, carbamazepine, cefotiam, ciprofloxacin, diazepam, diclofenac, doxycycline, ketamine, lorazepam, naproxen, and vancomycin. A major issue with these injury-induced modifications in pharmacokinetics is that some medications do not reach desired therapeutic effects, whereas others may reach potentially toxic levels. In addition to potential toxicity, also common side effects of medications (e.g., gastric emptying and gastrointestinal motility caused by opioids) may worsen the natural pathophysiology of injury. Post-marketing surveillance and risk assessment programs aim at detecting previously unrecognized positive or negative effects that may be associated with a medication - within real-world populations. To our knowledge, few of these studies have examined effects after spinal cord injury. An exemption is a recent study that established neurological safety profile of baclofen, an antispasmodic to treat debilitating muscle spasms. ${ }^{43}$ Cragg et al performed a secondary analysis of clinical trial data to provide data reaffirming that baclofen is neurologically, hepatically, and renally safe to use in patients sustaining a spinal cord injury. ${ }^{43}$ Complementing the existing safety profile, neurological safety medication profiles in the context of concomitant medications in real-world settings will enable health care providers to provide an informed, evidence-based response regarding the use of medications such as baclofen in the acute phase of spinal cord injury.

\section{Conclusion and implications for other neurological disorders}

Our study revealed that in the management of acute spinal cord injury, there is a dramatic degree of polypharmacy that could potentially impact recovery and the potency of novel treatments of spinal cord injury. It should be noted that in the testing of novel drug agents in preclinical models of spinal cord injury, the experiments are typically designed to minimize (and of course standardize) the concomitant medications administered to the animals. Our analysis reveals how starkly different these experimental conditions are from clinical reality. Spinal cord injury is a complex condition and as such, the pharmacologic needs are understandably high. While we are not arguing for an arbitrary "reduction" in the use of various medications in the management of these individuals, evaluating current standards of acute care and understanding what pharmacologic agents patients are typically exposed to does represent an intriguing alternative strategy to improve the lives of individuals with spinal cord injury, and at the least highlights the need for awareness when designing drug trials for the acute injury setting. Knowledge gained from our study has major implications for other diseases hallmarked by polypharmacy, including Parkinson's disease, ${ }^{44}$ Alzheimer's disease, ${ }^{45}$ Multiple Sclerosis, ${ }^{46}$ traumatic brain injury, ${ }^{47,48}$ cancer, ${ }^{49}$ and sepsis. ${ }^{50}$ Similar to spinal cord injury, these diseases are complex conditions associated with a wide range of symptoms (e.g., functional impairment) and secondary complications (e.g., gastrointestinal and cardiovascular complications, pain) necessitating pharmacological treatment - at times simultaneously. Many of these diseases are not yet curable, but effective disease modifying treatments that relieve symptoms, slow down disease progression, and improve quality of life are available. ${ }^{51-54} \mathrm{~A}$ cursory glance at the literature corroborates that the knowledge gap regarding the effect 
medRxiv preprint doi: https://doi.org/10.1101/2021.05.28.21257947; this version posted May 31, 2021. The copyright holder for this preprint

(which was not certified by peer review) is the author/funder, who has granted medRxiv a license to display the preprint in perpetuity.

It is made available under a CC-BY-NC 4.0 International license .

of commonly used medications on disease progression and their potential to alter the effectiveness of disease modifying treatments is not unique to spinal cord injury.

\section{Appendix 1: Authors}

\begin{tabular}{|c|c|c|}
\hline Name & Location & Contribution \\
\hline Catherine R. Jutzeler, PhD & $\begin{array}{l}\text { ETH Zurich and SIB Swiss Institute } \\
\text { of Bioinformatics, Basel, } \\
\text { Switzerland }\end{array}$ & $\begin{array}{l}\text { study concept/design, data entry, } \\
\text { data cleaning, data analyses, } \\
\text { interpretation of data, and drafting } \\
\text { the manuscript }\end{array}$ \\
\hline Lucie Bourguignon, MSc & $\begin{array}{l}\text { ETH Zurich and SIB Swiss Institute } \\
\text { of Bioinformatics, Basel, } \\
\text { Switzerland }\end{array}$ & $\begin{array}{l}\text { interpretation of data, and revising } \\
\text { the manuscript for intellectual } \\
\text { content }\end{array}$ \\
\hline Bobo Tong, MPH & $\begin{array}{l}\text { University of British Columbia, } \\
\text { Vancouver, Canada }\end{array}$ & $\begin{array}{l}\text { data cleaning, interpretation of data } \\
\text { and revising the manuscript for } \\
\text { intellectual content }\end{array}$ \\
\hline Elias Ronca, $\mathrm{PhD}$ & $\begin{array}{l}\text { Swiss Paraplegic Resarch, Nottwil, } \\
\text { Switzerland }\end{array}$ & $\begin{array}{l}\text { interpretation of data, and revising } \\
\text { the manuscript for intellectual } \\
\text { content }\end{array}$ \\
\hline Eric Bailey, BSc & $\begin{array}{l}\text { James J Peters Veterans Affairs } \\
\text { Medical Center, Bronx, New York }\end{array}$ & $\begin{array}{l}\text { data cleaning, interpretation of data, } \\
\text { and revising the manuscript for } \\
\text { intellectual content }\end{array}$ \\
\hline Noam Y. Harel, MD PhD & $\begin{array}{l}\text { James J Peters Veterans Affairs } \\
\text { Medical Center, Bronx, New York; } \\
\text { Icahn School of Medicine at Mount } \\
\text { Sinai, New York, New York }\end{array}$ & $\begin{array}{l}\text { data cleaning, interpretation of data, } \\
\text { and revising the manuscript for } \\
\text { intellectual content }\end{array}$ \\
\hline Fred Geisler, MD PhD & $\begin{array}{l}\text { University of Saskatchewan, } \\
\text { Saskatoon, Saskatchewan, Canada }\end{array}$ & $\begin{array}{l}\text { primary data collection, } \\
\text { interpretation of data, and revising } \\
\text { the manuscript for intellectual } \\
\text { content }\end{array}$ \\
\hline Adam R. Ferguson, $\mathrm{PhD}$ & $\begin{array}{l}\text { Brain and Spinal Injury Center, } \\
\text { Weill Institute for Neurosciences, } \\
\text { University of California San } \\
\text { Francisco (UCSF), San Francisco, } \\
\text { CA; San Francisco Veteran's } \\
\text { Affairs Health Care System, San } \\
\text { Francisco, CA }\end{array}$ & $\begin{array}{l}\text { revising the manuscript for } \\
\text { intellectual content }\end{array}$ \\
\hline Brian Kwon, MD PhD & $\begin{array}{l}\text { International Collaboration on } \\
\text { Repair Discoveries (ICORD), } \\
\text { University of British Columbia, } \\
\text { Vancouver, Canada. }\end{array}$ & $\begin{array}{l}\text { revising the manuscript for } \\
\text { intellectual content }\end{array}$ \\
\hline Jacquelyn Cragg, MPH PhD & $\begin{array}{l}\text { University of British Columbia, } \\
\text { Vancouver, Canada }\end{array}$ & $\begin{array}{l}\text { study concept/design, interpretation } \\
\text { of data, and revising the manuscript }\end{array}$ \\
\hline
\end{tabular}


medRxiv preprint doi: https://doi.org/10.1101/2021.05.28.21257947; this version posted May 31, 2021. The copyright holder for this preprint (which was not certified by peer review) is the author/funder, who has granted medRxiv a license to display the preprint in perpetuity.

It is made available under a CC-BY-NC 4.0 International license .

for intellectual content

Lukas Grassner, MD PhD

John LK Kramer, $\mathrm{PhD}$
Department of Neurosurgery, Medical University Innsbruck, Innsbruck, Austria primary data collection, interpretation of data, and revising the manuscript for intellectual content

University of British Columbia, study concept/design, interpretation Vancouver, Canada of data, and revising the manuscript for intellectual content 
medRxiv preprint doi: https://doi.org/10.1101/2021.05.28.21257947; this version posted May 31, 2021. The copyright holder for this preprint

(which was not certified by peer review) is the author/funder, who has granted medRxiv a license to display the preprint in perpetuity.

It is made available under a CC-BY-NC 4.0 International license .

\section{References}

1. Tator CH. Update on the Pathophysiology and Pathology of Acute Spinal Cord Injury. Brain Pathol. 1995;5:407-413.

2. Geisler FH, Coleman WP, Grieco G, Poonian D, Sygen Study Group. Recruitment and early treatment in a multicenter study of acute spinal cord injury. Spine (Phila Pa 1976). 2001;26:S58-S67.

3. Segal JL, Maltby BF, Langdorf MI, Jacobson R, Brunnemann SR, Jusko WJ. Methylprednisolone disposition kinetics in patients with acute spinal cord injury. Pharmacotherapy. 32676BC;18:16-22.

4. Hagen EM. Acute complications of spinal cord injuries. World J Orthop. Epub 2015.

5. Warner FM, Cragg JJ, Jutzeler CR, et al. Early Administration of Gabapentinoids Improves Motor Recovery after Human Spinal Cord Injury. Cell Rep. Epub 2017.

6. Cragg JJ, Haefeli J, Jutzeler CR, et al. Effects of pain and pain management on motor recovery of spinal cord-injured patients: A longitudinal study. Neurorehabil Neural Repair. Epub 2016.

7. Warner FM, Jutzeler CR, Cragg JJ, et al. The Effect of Non-Gabapentinoid Anticonvulsants on Sensorimotor Recovery After Human Spinal Cord Injury. CNS Drugs. Epub 2019.

8. Sun W, Larson MJE, Kiyoshi CM, et al. Gabapentinoid treatment promotes corticospinal plasticity and regeneration following murine spinal cord injury. J Clin Invest. Epub 2020.

9. Tedeschi A, Dupraz S, Laskowski CJ, et al. The Calcium Channel Subunit Alpha2delta2 Suppresses Axon Regeneration in the Adult CNS. Neuron. 2016;92:419-434.

10. von Elm E, Altman D, Pocock D, Gotzsche, Peter; Vandenbroucke J. Strengthening the reporting of observational studies in epidemiology (STRO BE) statement: guidelines for reporting observational studies. BMJ Br Med \{...\}. 2007;335:20-22.

11. Geisler FH, Dorsey FC, Coleman WP. Recovery of motor function after spinal-cord injury--a randomized, placebo-controlled trial with GM-1 ganglioside. N Engl J Med. 1991;324:1829-1838.

12. Hadley MN, Walters BC. Introduction to the Guidelines for the Management of Acute Cervical Spine and Spinal Cord Injuries. Neurosurgery. 2013;72:5-16.

13. Hadley MN, Walters BC, Grabb PA, et al. Guidelines for the management of acute cervical spine and spinal cord injuries. Clin. Neurosurg. 2002. p. 407-498.

14. Fawcett JW, Curt A, Steeves JD, et al. Guidelines for the conduct of clinical trials for spinal cord injury as developed by the ICCP panel: spontaneous recovery after spinal cord injury and statistical power needed for therapeutic clinical trials. Spinal Cord. 2007;45:190-205. 
medRxiv preprint doi: https://doi.org/10.1101/2021.05.28.21257947; this version posted May 31, 2021. The copyright holder for this preprint

(which was not certified by peer review) is the author/funder, who has granted medRxiv a license to display the preprint in perpetuity.

It is made available under a CC-BY-NC 4.0 International license .

15. Steeves JD, Kramer JK, Fawcett JW, et al. Extent of spontaneous motor recovery after traumatic cervical sensorimotor complete spinal cord injury. Spinal Cord. 2011;49:257-265.

16. Whiteneck G, Gassaway J, Dijkers M, Jha A. New approach to study the contents and outcomes of spinal cord injury rehabilitation: The SCIRehab project. J. Spinal Cord Med. 2009.

17. Whiteneck G, Gassaway J, Dijkers M, et al. The SCIRehab project: treatment time spent in SCI rehabilitation. Inpatient treatment time across disciplines in spinal cord injury rehabilitation. J Spinal Cord Med. Epub 2011.

18. Cancer Therapy Evaluation Program. Common terminology criteria for adverse events v5.0. UpToDate 2017.

19. MedDra. Medical Dictionary for Regulatory Activities.

20. Chang W, Cheng J, Allaire J, Xie Y, McPherson J. Package “shiny ": Web Application Framework for R. R Packag. version 2020.

21. R Core team. R Core Team. R A Lang. Environ. Stat. Comput. R Found. Stat. Comput., Vienna, Austria. ISBN 3-900051-07-0, URL http//www.R-project.org/. 2015. p. 275-286.

22. Chang W, Ribeiro BB. Package "ShinyDashboard": Create Dashboards with "Shiny.” Epub 2018.:27.

23. Geisler FH, Coleman WP, Grieco G, Poonian D, Group SS, Sygen Study Group. The Sygen multicenter acute spinal cord injury study. Spine (Phila Pa 1976). 2001;26:S87-98.

24. Ben-Menachem E. Pregabalin pharmacology and its relevance to clinical practice. Epilepsia. 2004.

25. Wu D, Kang YS, Bickel U, Pardridge WM. Blood-brain barrier permeability to morphine-6-glucuronide is markedly reduced compared with morphine. Drug Metab Dispos. Epub 1997.

26. Viktil KK, Blix HS, Moger TA, Reikvam A. Polypharmacy as commonly defined is an indicator of limited value in the assessment of drug-related problems. Br J Clin Pharmacol. Epub 2007.

27. Gnjidic D, Hilmer SN, Blyth FM, et al. Polypharmacy cutoff and outcomes: Five or more medicines were used to identify community-dwelling older men at risk of different adverse outcomes. J Clin Epidemiol. Epub 2012.

28. Hook MA, Moreno G, Woller S, et al. Intrathecal Morphine Attenuates Recovery of Function after a Spinal Cord Injury. J Neurotrauma. 2009;26:741-752.

29. Hook MA, Woller SA, Bancroft E, et al. Neurobiological Effects of Morphine after Spinal Cord Injury. J Neurotrauma. 2017;34:632-644.

30. Faden AI, Jacobs TP, Holaday JW. Opiate antagonist improves neurologic recovery after spinal injury. 
medRxiv preprint doi: https://doi.org/10.1101/2021.05.28.21257947; this version posted May 31, 2021. The copyright holder for this preprint

(which was not certified by peer review) is the author/funder, who has granted medRxiv a license to display the preprint in perpetuity.

It is made available under a CC-BY-NC 4.0 International license .

Science (80- ). Epub 1981.

31. Faden AI, Jacobs TP, Holaday JW. Comparison of early and late naloxone treatment in experimental spinal injury. Neurology. Epub 1982.

32. Stampas A, Pedroza C, Bush JN, Ferguson AR, Kramer JLK, Hook M. The first 24 h: opioid administration in people with spinal cord injury and neurologic recovery. Spinal Cord. Epub 2020.

33. Goplen CM, Verbeek W, Kang SH, et al. Preoperative opioid use is associated with worse patient outcomes after Total joint arthroplasty: A systematic review and meta-analysis. BMC Musculoskelet Disord. Epub 2019.

34. Mestre H, Alkon T, Salazar S, Ibarra A. Spinal cord injury sequelae alter drug pharmacokinetics: An overview. Spinal Cord 2011.

35. Reihani-Kermani H, Ansari M, Karamousian S. The influence of experimental spinal cord injury on carbamazepine pharmacokinetics. Arch Iran Med. Epub 2006.

36. Fuentes-Lara G, Guízar-Sahagún G, García-López P. Effect of experimental spinal cord injury on salicylate bioavailability after oral aspirin administration. J Pharmacol Toxicol Methods. Epub 1999.

37. García-López P, Martínez-Cruz A, Guízar-Sahagún G, Castãeda-Hernández G. Acute spinal cord injury changes the disposition of some, but not all drugs given intravenously. Spinal Cord. Epub 2007.

38. Hijazi Y, Bodonian C, Bolon M, Salord F, Boulieu R. Pharmacokinetics and haemodynamics of ketamine in intensive care patients with brain or spinal cord injury. Br J Anaesth. Epub 2003.

39. Segal JL, Brunnemann SR, Eltorai IM, Vulpe M. Decreased Systemic Clearance of Lorazepam in Humans With Spinal Cord Injury. J Clin Pharmacol. Epub 1991.

40. IBARRA A, GUÍZAR-SAHAGÚN G, CORREA D, et al. Alteration of Cyclosporin-A Pharmacokinetics after Experimental Spinal Cord Injury. J Neurotrauma. Epub 2009.

41. Segal JL, Brunnemann SR. Clinical Pharmacokinetics in Patients with Spinal Cord Injuries. Clin. Pharmacokinet. 1989.

42. García-López P, Salas R. Bioavailability of diclofenac after intramuscular administration to rats with experimental spinal cord injury. J Pharmacol Toxicol Methods. Epub 1999.

43. Cragg JJ, Tong B, Jutzeler CR, et al. A Longitudinal Study of the Neurologic Safety of Acute Baclofen Use After Spinal Cord Injury. Neurotherapeutics. Epub 2019.

44. McLean G, Hindle J V., Guthrie B, Mercer SW. Co-morbidity and polypharmacy in Parkinson's disease: Insights from a large Scottish primary care database. BMC Neurol. Epub 2017. 
medRxiv preprint doi: https://doi.org/10.1101/2021.05.28.21257947; this version posted May 31, 2021. The copyright holder for this preprint

(which was not certified by peer review) is the author/funder, who has granted medRxiv a license to display the preprint in perpetuity.

It is made available under a CC-BY-NC 4.0 International license .

45. Fereshtehnejad SM, Johnell K, Eriksdotter M. Anti-dementia drugs and co-medication among patients with Alzheimer's disease: Investigating real-world drug use in clinical practice using the Swedish Dementia Quality Registry (SveDem). Drugs and Aging. Epub 2014.

46. Thelen JM, Lynch SG, Bruce AS, Hancock LM, Bruce JM. Polypharmacy in multiple sclerosis:

Relationship with fatigue, perceived cognition, and objective cognitive performance. J Psychosom Res.

Epub 2014.

47. Cosano G, Giangreco M, Ussai S, et al. Polypharmacy and the use of medications in inpatients with acquired brain injury during post-acute rehabilitation: A cross-sectional study. Brain Inj. Epub 2016.

48. Haddad SH, Arabi YM. Critical care management of severe traumatic brain injury in adults. Scand. J. Trauma. Resusc. Emerg. Med. 2012.

49. Kierner KA, Weixler D, Masel EK, Gartner V, Watzke HH. Polypharmacy in the terminal stage of cancer. Support Care Cancer. Epub 2016.

50. Mcallister TA. POLYPHARMACY IN SEPSIS. Lancet 1973.

51. Ghezzi L, Scarpini E, Galimberti D. Disease-modifying drugs in Alzheimer's disease. Drug Des. Devel. Ther. 2013.

52. Cummings J, Fox N. Defining Disease Modifying Therapy for Alzheimer's Disease. J Prev Alzheimer's Dis. Epub 2017.

53. Lang AE, Espay AJ. Disease Modification in Parkinson's Disease: Current Approaches, Challenges, and Future Considerations. Mov. Disord. 2018.

54. Schulenborg T, Schmidt O, Van Hall A, Meyer HE, Hamacher M, Marcus K. Proteomics in neurodegeneration - Disease driven approaches. J. Neural Transm. 2006. 


\section{FIGURE CAPTION}

Figure 1. Pharmacological management of acute spinal cord injury. (A) Secondary complications. Spinal cord injury is associated with a large number of secondary complications that arise from 20 organ systems as defined by Common Terminology Criteria for Adverse Events (CTCAE) published by U.S. Department of Health and Human Services ${ }^{26}$ Many medications were also administered to facilitate medical and surgical procedures, such as decompression surgeries, laminectomy, and computer tomography scans. (B) Number of medications administered to patients enrolled in the Sygen trial within the first 7, 14, 30, and 60 days post-injury. (C) Number of medications administered to patients enrolled in the SCIRehab study within the first 7, 14, 30, and 60 days postinjury. (D) Frequency of medications administered. The majority of patients enrolled in the Sygen trial received acetaminophen, morphine, and heparin to treat secondary complications, such as pain and deep venous thrombosis. (E) Frequency of medications administered. Pain killers (acetaminophen and Acetaminophen oxycodone) as well as the laxative docusate were among the most frequently administered medications in the SCIRehab study.

Figure 2. Indication of medications administered. A) Number of unique medications administered per organ system for patients enrolled in the Sygen clinical trial. Note the diversity of medications administered within each category of complications. For instance, over 100 different medications were administered to treat infections and infestations as well as for surgical and medical procedures. (B) Number of patients of the Sygen clinical trial that required treatment per organ system. The three most frequently treated secondary complications were pain, gastro-intestinal system disorders, as well as infections. The SCIRehab database did not track the indications for which medications were prescribed.

Figure 3. Polypharmacy. (A) Point prevalence of commonly administered medications. The number of medications administered per day per patient in the first 60 days post injury varied between 1 and 30 for the clinical trial and between 1 and 43 in the observational study. Each line represents one patient and the color white indicates that no medication was administered or no data was available for that time period. (B) Daily average number of medications administered. Patients with motor complete injuries (AIS A and B) received on average more medications per day compared to patients with motor incomplete injuries. The range medications administered varies quite drastically. The dashed line denotes the average number of medications and the solid lines the minimum and maximum number of medications, respectively. Patients with no information on AIS grades at baseline were grouped together in the category 'unknown'. (C) Examples longitudinal medication profiles for four patients in the first 60 days post injury. Polypharmacy was commonplace across different injury severities and aetiologies. The pattern of medication administration varied between continuous, intermittent, and single-use indications. Medications were often co-administered bearing a high risk of pharmacological interactions between medications. While some are well-understood, the majority of these interactions (particularly combinations of three and more medications) have not yet been explored. (D) Network of medications administered in combination to patients enrolled in the Sygen trial. The nodes of the network represent the medications. The size of the nodes represents the number of patients that have received this particular medication on day 7 or 14, respectively. Medications that were administered together on a specific day, either 7 or 14, are connected via an edge. The width of the edge represents the number of patients that have received the two medications (acetaminophen and ketorolac) in combination on the day of interest. (E) Network of medications administered in combination to patients enrolled in the SCIRehab study. The nodes of the network represent the medications. The size of the nodes represents the number of patients that have received this particular medication on day 7 or 14, respectively.

Figure 4. Prophylactic pharmacological treatment to prevent secondary complications from occurring. (A) Number of indications per organ system. The majority of prophylactic indications were related to the gastrointestinal and vascular system as well as infections of all sorts. (B) Number of unique medications administered to for disease prophylaxis. (C) Number of indications per medications. Anticoagulants, antihistamines, and antibiotics were amongst the most frequently administered medication classes. (D) Number of patients that received prophylactic treatment per organ system. The majority of the patients enrolled in the Sygen trial $(n=666[83.6 \%])$ received at least one medication for disease prophylaxis. The average number of medications per patient was 3 (range: 1-21) and average number of indications per patient was 4.3 (1-33). 
medRxiv preprint doi: https://doi.org/10.1101/2021.05.28.21257947; this version posted May 31, 2021. The copyright holder for this preprint (which was not certified by peer review) is the author/funder, who has granted medRxiv a license to display the preprint in perpetuity.

It is made available under a CC-BY-NC 4.0 International license .

Table 1. Demographics and injury characteristics of the included cohorts.

\begin{tabular}{|c|c|c|c|}
\hline & $\begin{array}{l}\text { Sygen Clinical Trial } \\
\qquad(\mathrm{n}=797)\end{array}$ & & $\begin{array}{l}\text { SCIRehab Study } \\
\quad(\mathrm{n}=1243)\end{array}$ \\
\hline \multicolumn{4}{|l|}{ Study details } \\
\hline Study type & $\begin{array}{l}\text { Prospective, double-blind, } \\
\text { randomized, stratified, } \\
\text { multicenter trial }\end{array}$ & & Prospective observational study \\
\hline Study outcome & $\begin{array}{c}\text { No differences between treatment } \\
\text { and placebo groups in terms of } \\
\text { neurological recovery }\end{array}$ & & -- \\
\hline Running time & 1992-1998 & & $2007-2010$ \\
\hline Country & United States of America & & United States of America \\
\hline Time of enrollment & $<72 \mathrm{hrs}$ & & $\begin{array}{l}\text { Admission to rehabilitation center } \\
\text { (30 } \pm 27 \text { days post injury) }\end{array}$ \\
\hline Follow-up & 1-year post-injury & & Discharge from rehabilitation center \\
\hline References & $\begin{array}{c}\text { PMID [11805612], [1180561], } \\
{[2041549]}\end{array}$ & & PMID [19810627] \\
\hline \multicolumn{4}{|l|}{ Sex, n (\%) } \\
\hline Female & $153(19.2 \%)$ & & $231(18.6 \%)$ \\
\hline Male & $642(80.6 \%)$ & & $1012(81.4 \%)$ \\
\hline Missing & $2(0.3 \%)$ & & $0(0 \%)$ \\
\hline Age (years) & \multicolumn{3}{|c|}{ Age Groups (years) } \\
\hline Mean (SD) & $32.5(13.4)$ & $12-19$ & $183(14.7 \%)$ \\
\hline Median [Min, Max] & $30.0[11.0,69.0]$ & $20-29$ & $340(27.4 \%)$ \\
\hline \multirow[t]{6}{*}{ Missing } & $2(0.3 \%)$ & $30-39$ & $190(15.3 \%)$ \\
\hline & & $40-49$ & $201(16.2 \%)$ \\
\hline & & $50-59$ & $165(13.3 \%)$ \\
\hline & & $60-69$ & $106(8.5 \%)$ \\
\hline & & $70-79$ & $45(3.6 \%)$ \\
\hline & & $80+$ & $13(1.0 \%)$ \\
\hline \multicolumn{4}{|l|}{ AIS Grade*, n (\%) } \\
\hline A & $446(56.0 \%)$ & A & $624(50.2 \%)$ \\
\hline B & $77(9.7 \%)$ & B & $192(15.4 \%)$ \\
\hline $\mathrm{C}$ & $149(18.7 \%)$ & $\mathrm{C}$ & $230(18.5 \%)$ \\
\hline $\mathrm{D}$ & $31(3.9 \%)$ & $\mathrm{D}$ & $197(15.8 \%)$ \\
\hline Missing & $94(11.8 \%)$ & & \\
\hline \multicolumn{4}{|c|}{ Neurological level of injury, $n$ (\%) } \\
\hline Cervical & $599(75.2 \%)$ & & $751(60.4 \%)$ \\
\hline Thoracic & $196(24.6 \%)$ & & $46(3.7 \%)$ \\
\hline Lumbar & - & & $446(35.9 \%)$ \\
\hline Missing & $2(0.3 \%)$ & & \\
\hline \multicolumn{4}{|c|}{ Paraplegia/Tetraplegia, n (\%) } \\
\hline Paraplegia & $189(23.6 \%)$ & Paraplegia & $461(37.1 \%)$ \\
\hline
\end{tabular}


medRxiv preprint doi: https://doi.org/10.1101/2021.05.28.21257947; this version posted May 31, 2021. The copyright holder for this preprint (which was not certified by peer review) is the author/funder, who has granted medRxiv a license to display the preprint in perpetuity.

It is made available under a CC-BY-NC 4.0 International license .

$\begin{array}{lccc}\text { Tetraplegia } & 602(76.1 \%) & \text { Tetraplegia } & 782(62.9 \%) \\ \text { Unknown } & 2(0.3 \%) & \text { Unknown } & -\end{array}$

Cause, n (\%)

\begin{tabular}{|c|c|c|}
\hline Automobile & $382(47.9 \%)$ & $441(35.5 \%)$ \\
\hline Blunt trauma & $9(1.1 \%)$ & - \\
\hline Fall & $129(16.2 \%)$ & $300(24.1 \%)$ \\
\hline Gunshot wound & $36(4.5 \%)$ & $125(10.1 \%)$ \\
\hline Motorcycle & $48(6.0 \%)$ & $110(8.8 \%)$ \\
\hline Sports & $35(4.4 \%)$ & $125(10.1 \%)$ \\
\hline Others & $61(7.7 \%)$ & $51(4.1 \%)$ \\
\hline Pedestrian & $10(1.3 \%)$ & $20(1.6 \%)$ \\
\hline $\begin{array}{l}\text { Person-to-person } \\
\text { contact }\end{array}$ & - & $10(0.8 \%)$ \\
\hline Water related & $85(10.7 \%)$ & $61(4.9 \%)$ \\
\hline Missing & $2(0.3 \%)$ & - \\
\hline
\end{tabular}

*American Spinal Injury Association Impairment Scale (AIS): AIS-A, no sensory or motor function is preserved in the sacral segments S4-5. AIS-B, sensory but no motor function is preserved below the neurological level and includes the sacral segments S4-5 (LT or PP at S4-5 or DAP), and no motor function is preserved more than three levels below the motor level on either side of the body. AIS-C, motor function is preserved at the most caudal sacral segments for voluntary anal contraction OR the patient meets the criteria for sensory incomplete status, and has some sparing of motor function more than three levels below the ipsilateral motor level on either side of the body. Less than half of key muscle functions below the single NLI have a muscle grade $\geq 3$. AIS-D, motor incomplete status as defined above, with at least half (half or more) of key muscle functions below the single NLI having a muscle grade $\geq 3$. AIS-E, if sensation and motor function as tested with the ISNCSCI are graded as normal in all segments, and the patient had prior deficits, then the AIS grade is E. Someone without an initial SCI does not receive an AIS grade. 
B

D
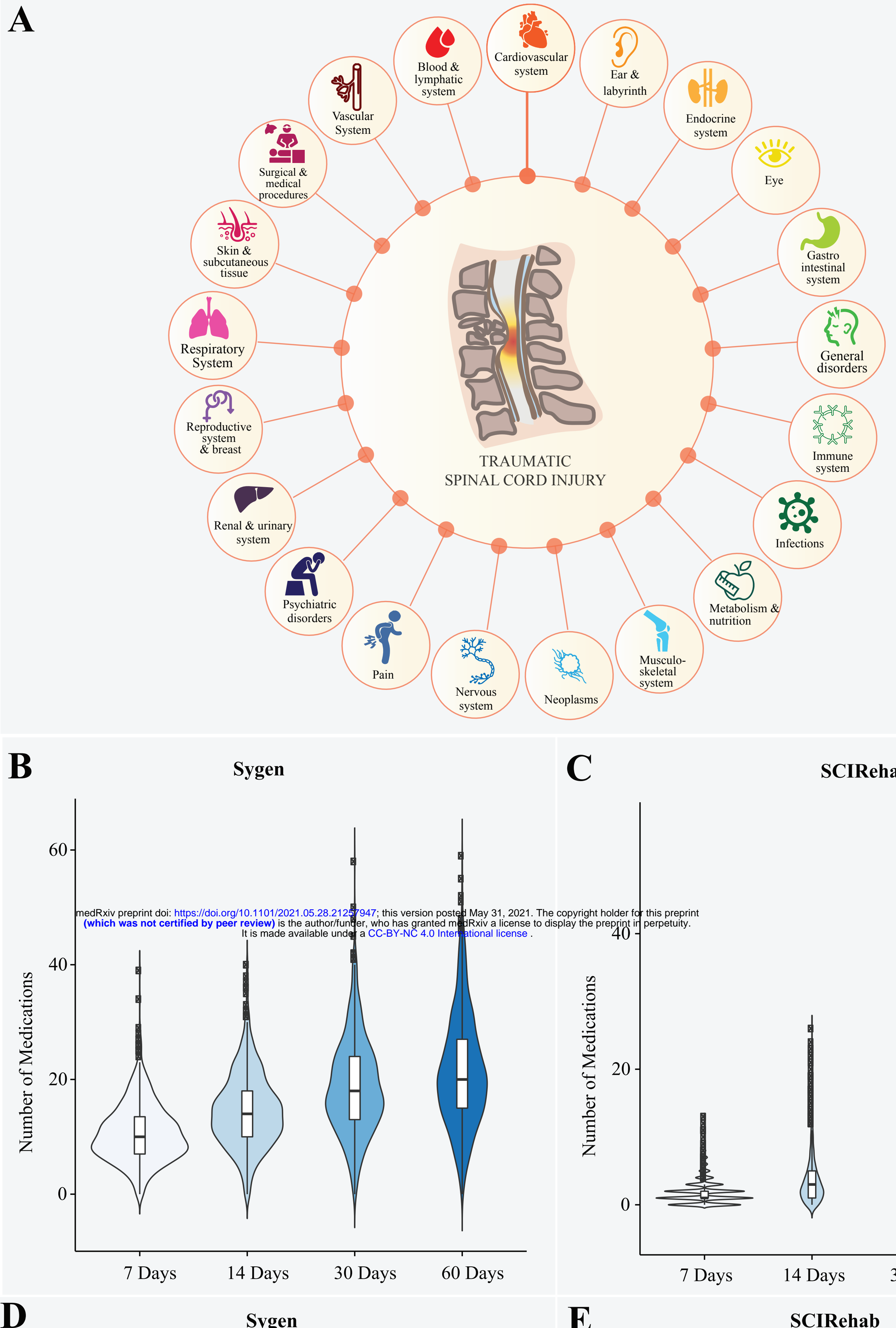

\section{Sygen}

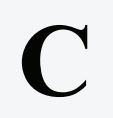

SCIRehab

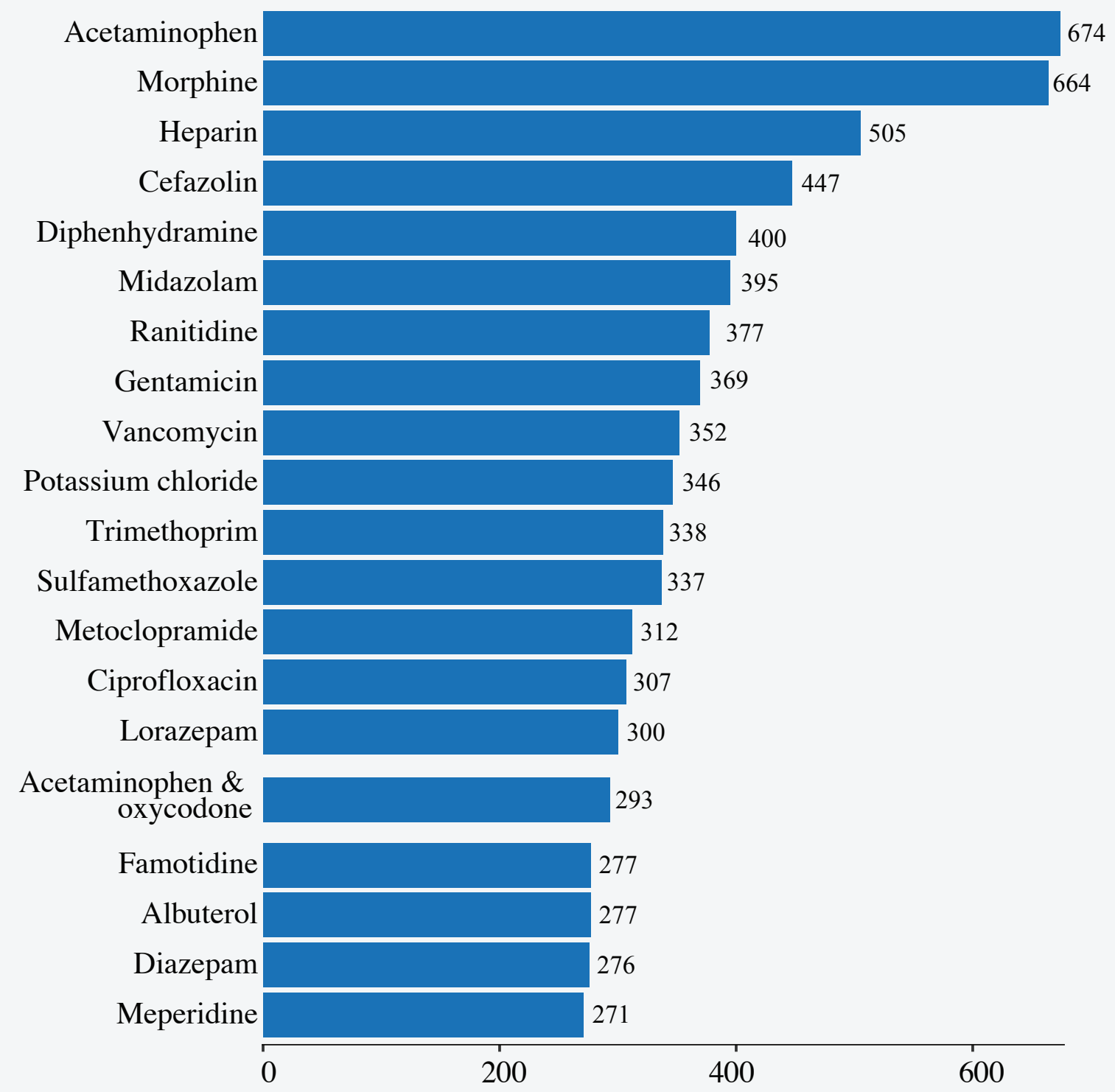

Number of Patients



E

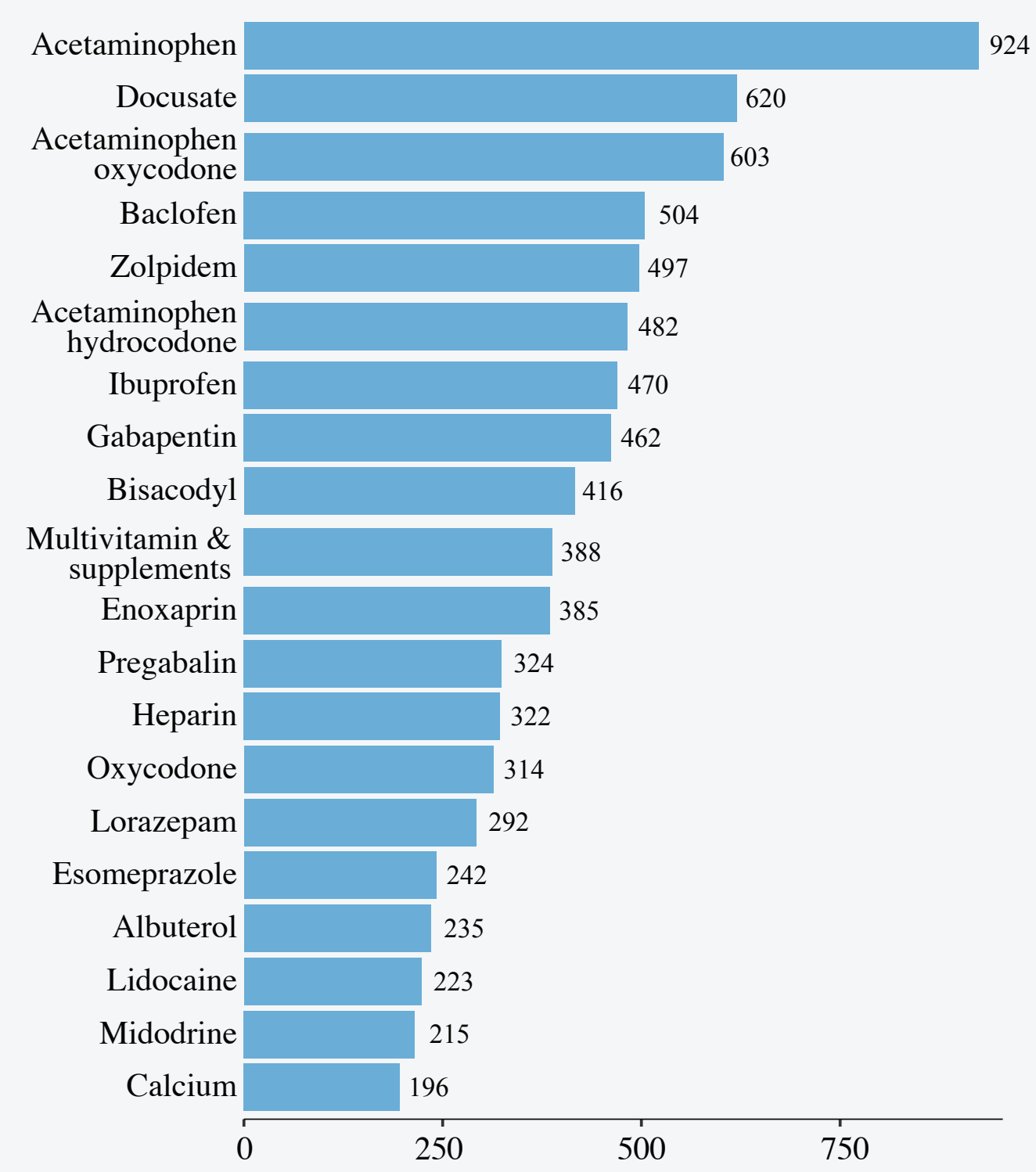


Vascular System

Surgical and medical procedures
Blood and lymphatic system

Cardiac System

Skin and subcutaneous tissue

Respiratory System

Reproductive system and breast

Renal and urinary system

Psychiatric Disorders

Pain

Nervous system

Neoplasms

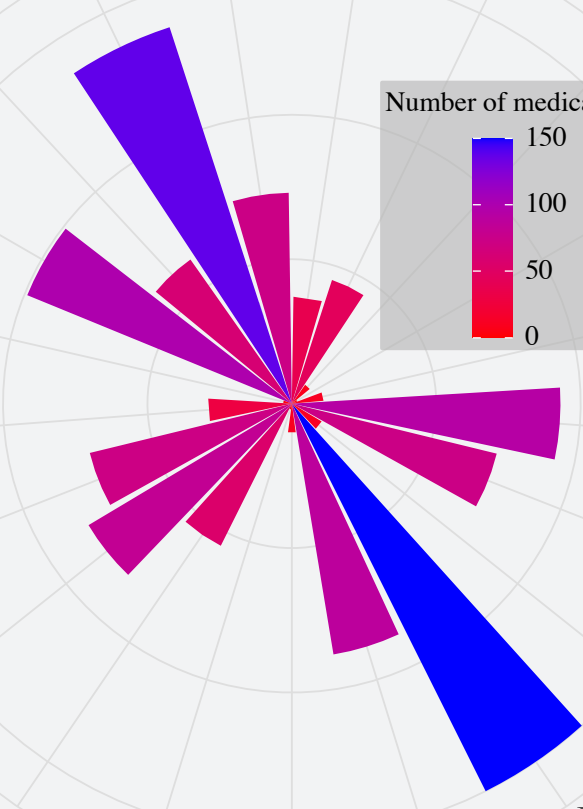

Ear and labyrinth

\section{Number of Patients per Indication}

\section{Vascular System}

Surgical and medical procedures

Skin and subcutaneous tissue

Respiratory System

Reproductive system and breast

Renal and urinary system

Psychiatric Disorders

Pain

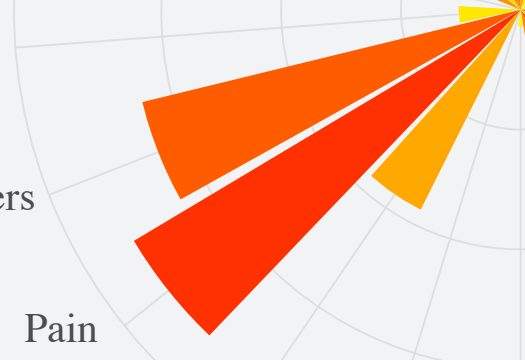

Nervous system

Neoplasms
Blood and lymphatic system

Cardiac System

Gastrointestinal System

General Disorders

Immune system

Infections

Metabolism and nutrition

Eye disorders

Ear and labyrinth

Number of patients

800
-600
-400
-200
-0

Endocrine System

Eye disorders

Gastrointestinal System

General Disorders

Immune system 


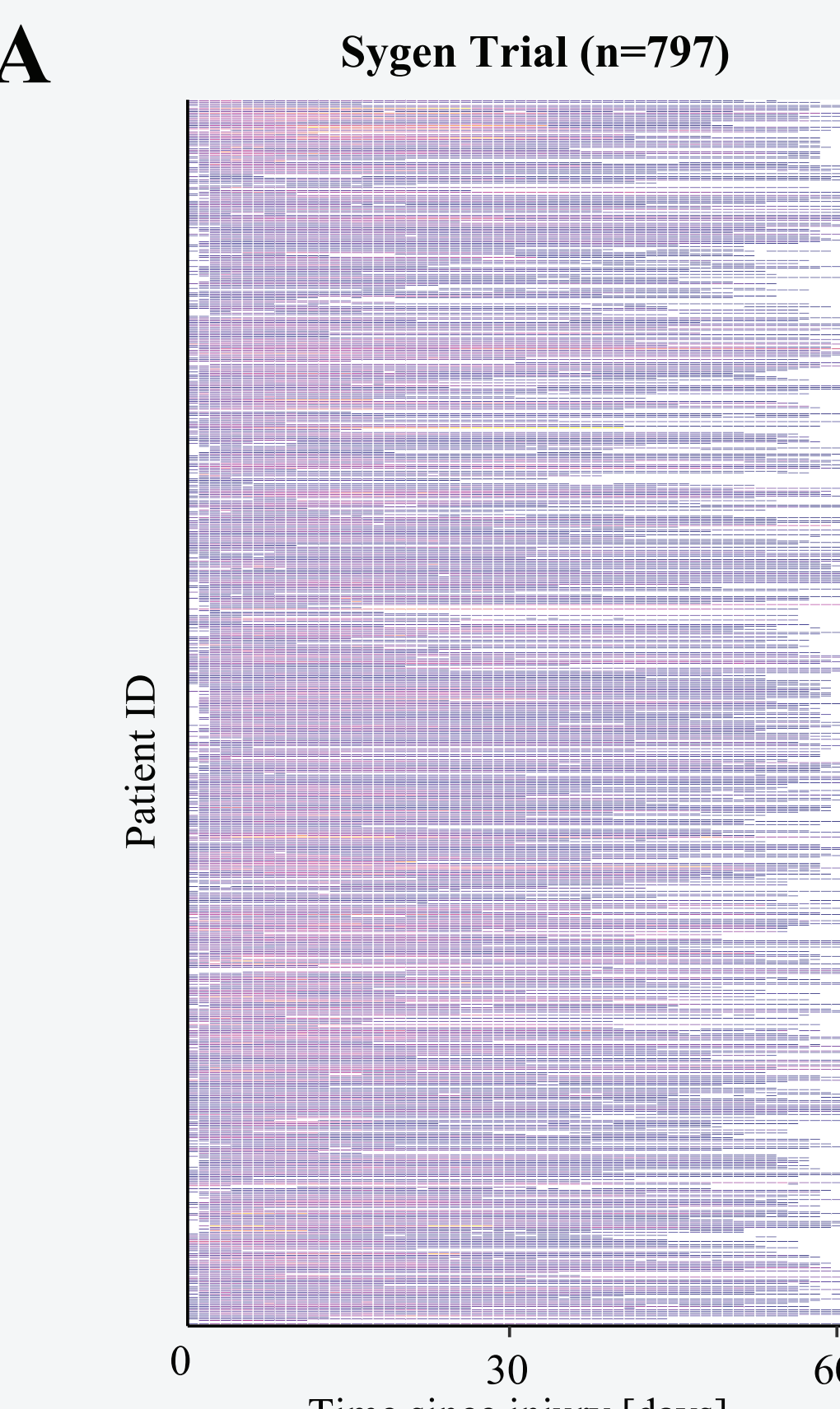

Time since injury [days]
SCI Rehab Study (n=1243)

B



$\begin{array}{ccc}10 & 20 & 30 \\ \text { Number of Drugs Administered }\end{array}$
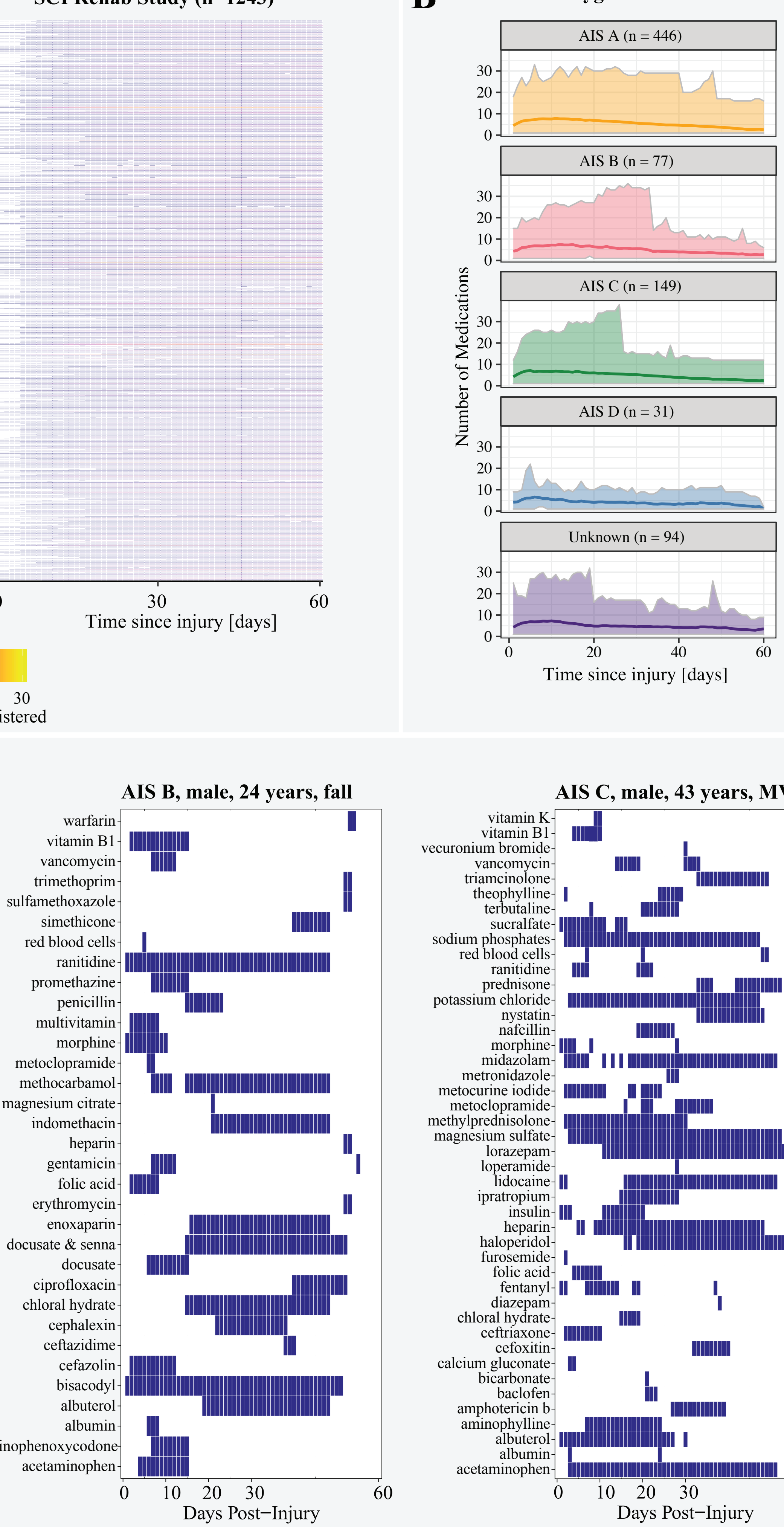

SYGEN



AIS C, male, 43 years, MVA




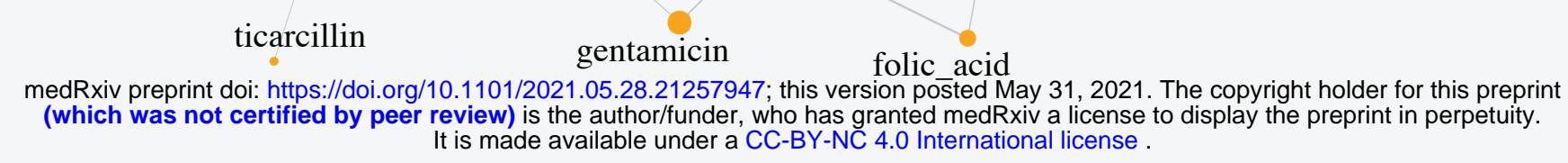

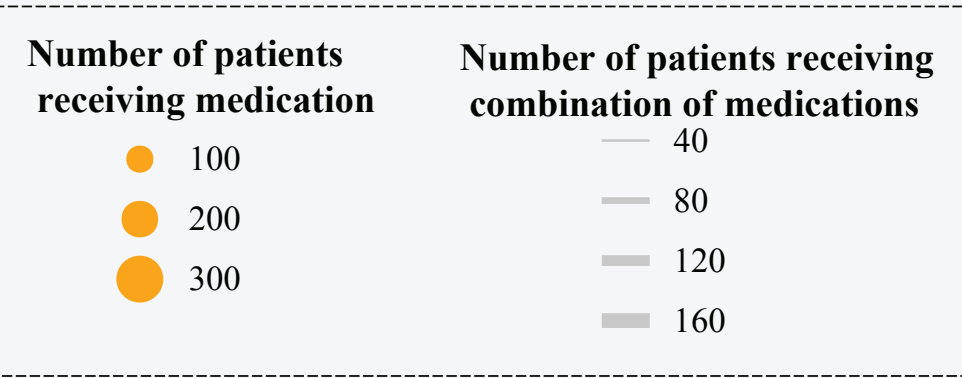

Day 7

$\mathbf{E}$

Day 7

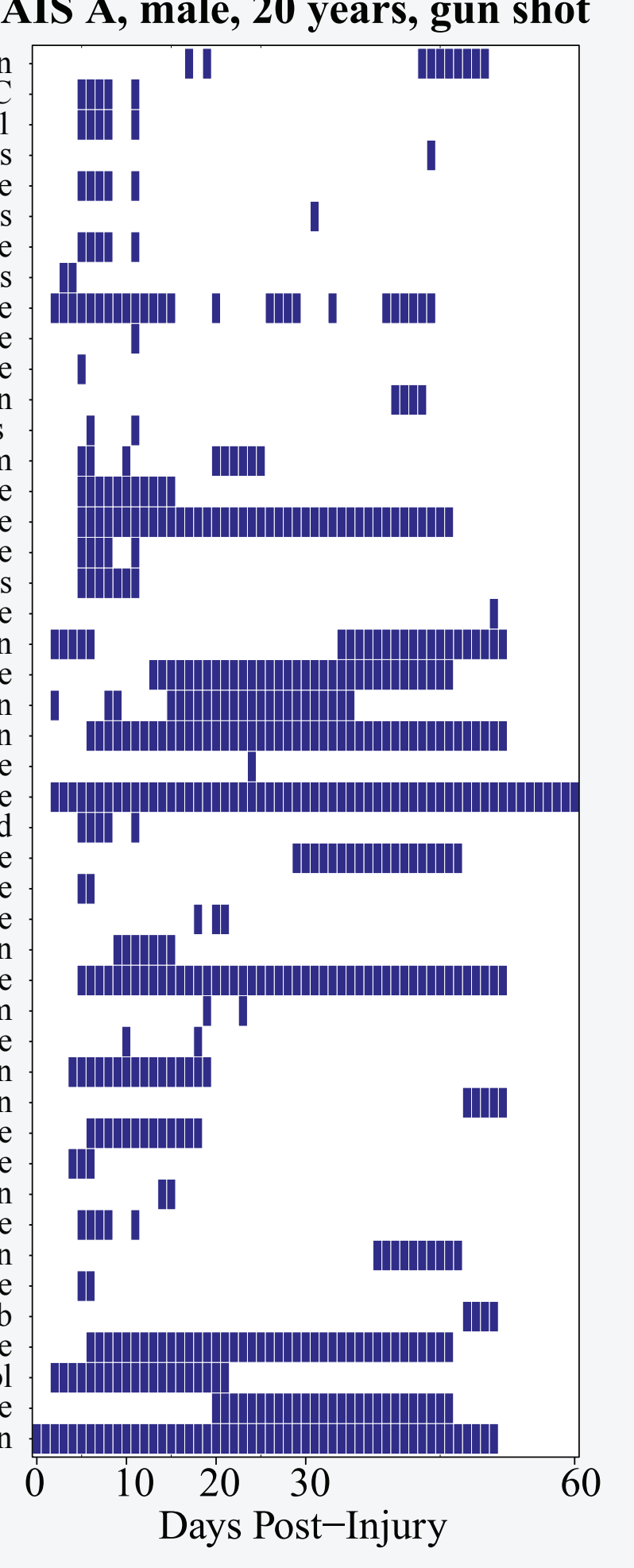$$
\text { The }
$$

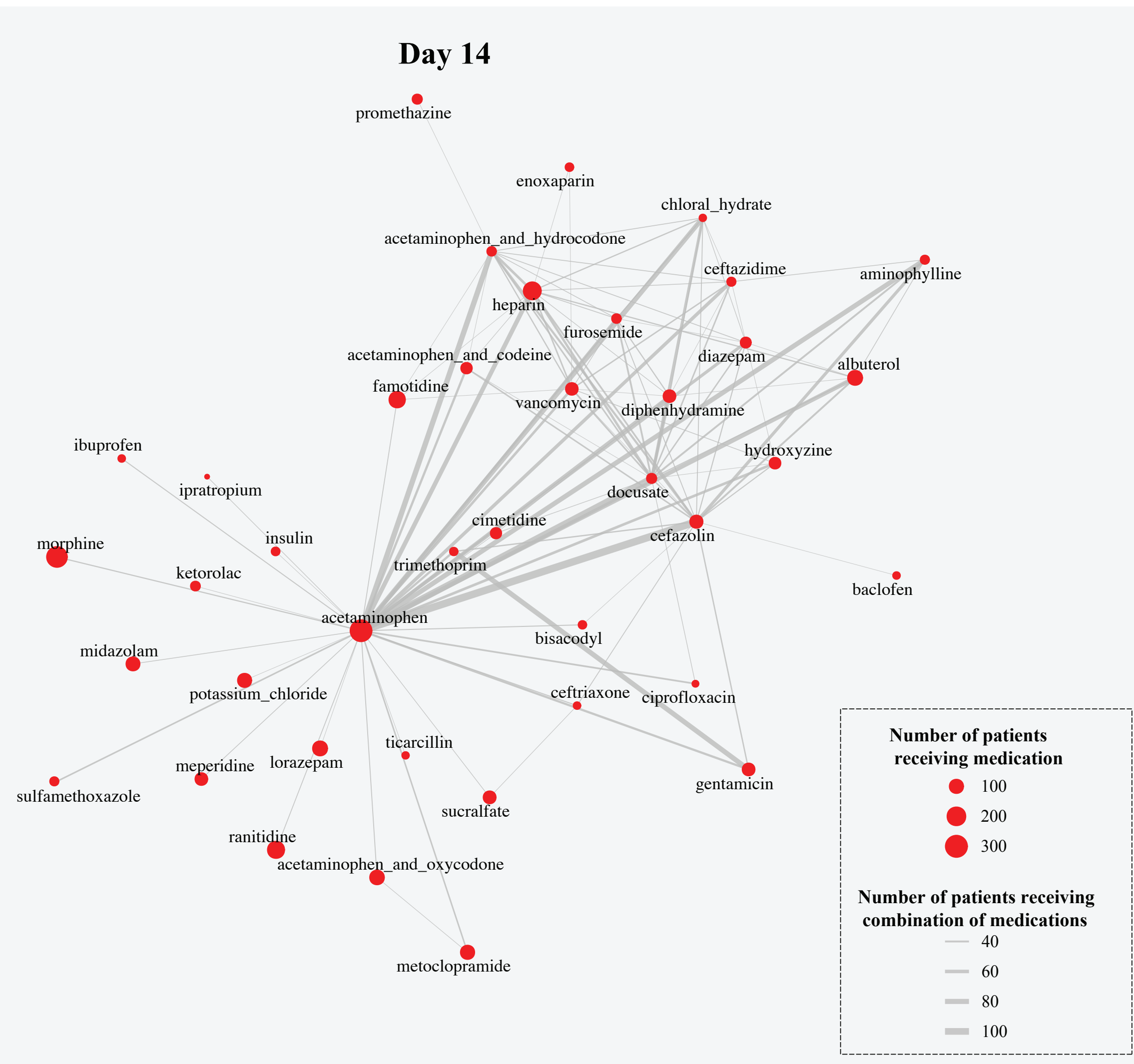

SCIREHAB

Day 14

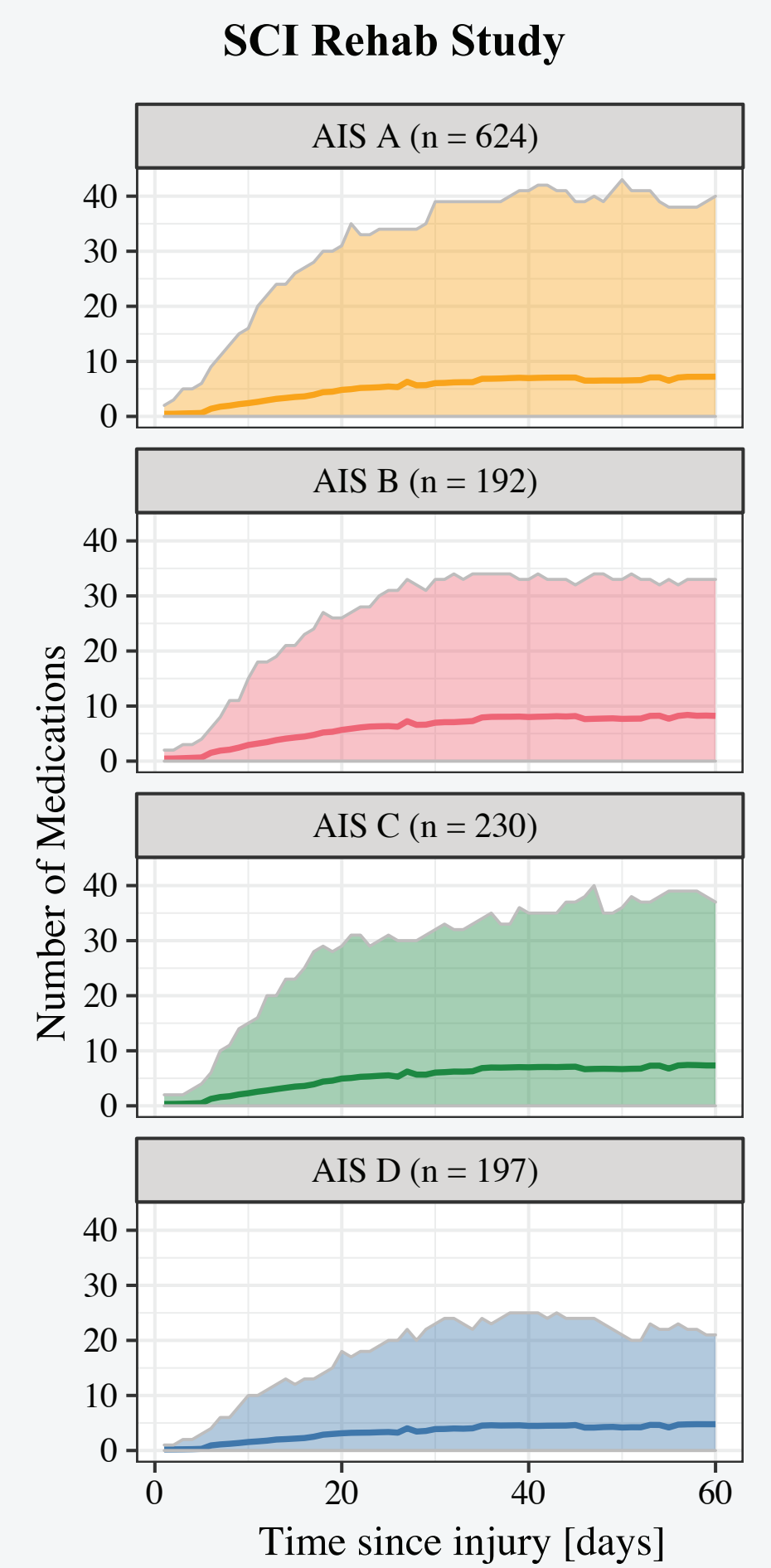




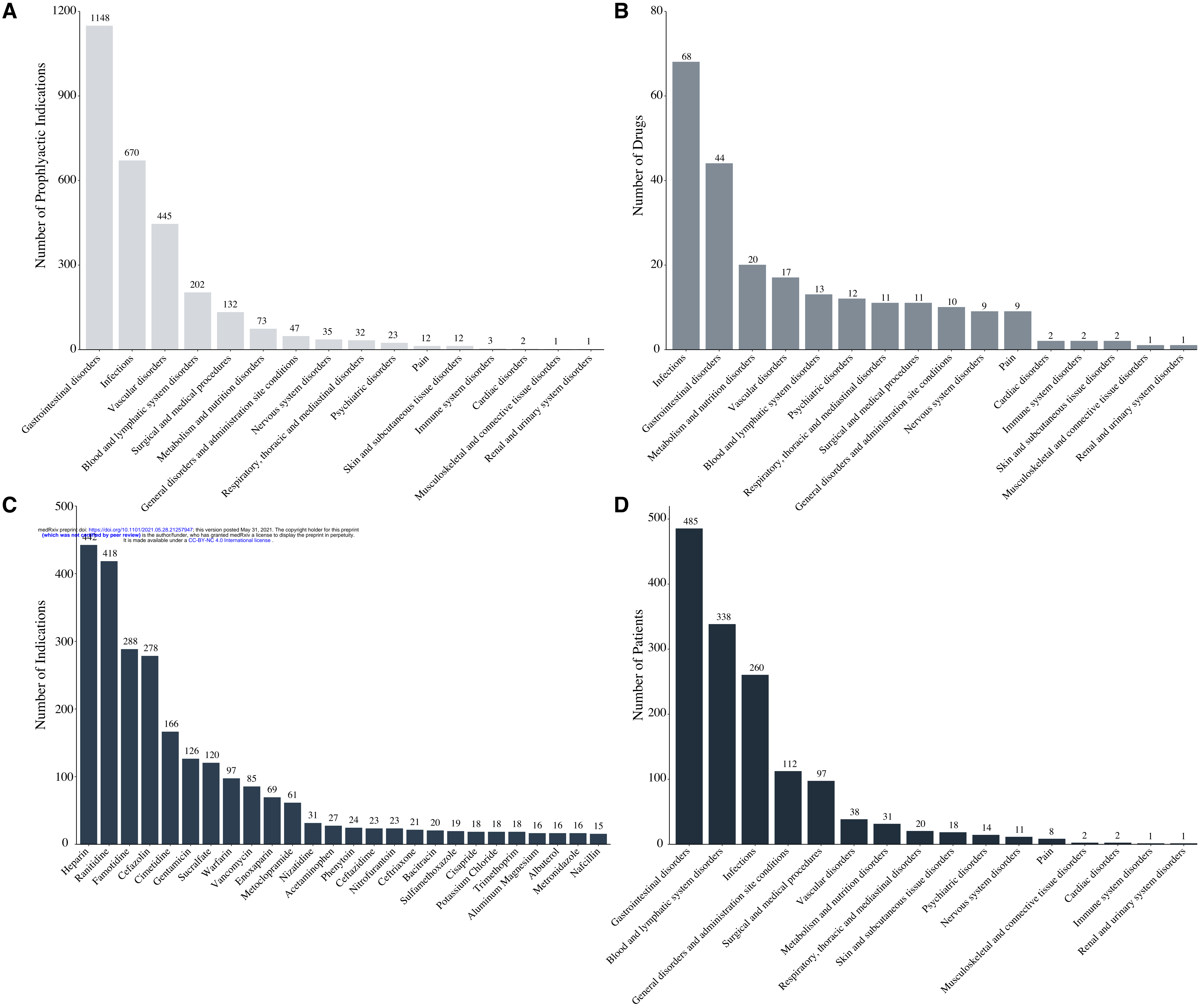

